\title{
Yerel Yönetimlerde Etkinlik ve Demokrasi Sorunsalı
}

\author{
Hatun Korkmaz ${ }^{1}$
}

Öz

Değişen dünya parametrelerine uygun bir kent yönetiminin nasıl bir modelle sağlanacağı sorunsalı öteden beri süregelmektedir. Bu konuda birbirinden farklı uygulamalar iki ana eksen üzerinde şekillenmektedir. İlk eksen, hizmetlerin hangi ölçekte daha etkin ve verimli sunulacağı, ikinci eksen ise, yerel demokrasinin nasıl daha fazla güçleneceğidir. Bu iki zıt uygulama konusunda, henüz bir mutabakat sağlanmamıştır. Zira, ölçek büyüdükçe demokrasiden uzaklaşılmakta, buna rağmen hizmetler daha etkin ve verimli dağılmakta, ayrıca hizmet sunum maliyeti de en aza inebilmektedir. Bu çalışmada, yerel yönetimlerin hizmet sunumunda etkinliği ve demokrasi sorunsalı dünya ve Türkiye'deki örnekleri ile karşılaştırmalı olarak açıklanmaya çalışılacaktır.

Anahtar Kelimeler: Etkinlik, Demokrasi, Optimal ölçek, Yerel yönetimler.

\section{Efficiency and Democracy Problematic in Local Governments}

\begin{abstract}
The problematic of which model to ensure proper urban management is debated for a long time. In this regard different applications is shaped around two main axis. The first axisis whether, how to be create the scale of which will offer services more effectively and efficiently. The second axis is whether how to strengthen local democracy further more. In these two contrasting ways, it has not yet achieved a consensus. In fact, when the local governments scale grows, it is moving away from democracy. However, public services are distributed more efficiently and effectively, but also in the public service provision costs can be minimized. In this study, effectiveness of service delivery of local government and democracy contradictions will be debated with the examples of World and Turkey.
\end{abstract}

Key Words: Effectiveness, Democracy, Local governments, Optimal scale.

1 Öğr. Gör., Erciyes Üniversitesi, İktisadi ve İdari Bilimler Fakültesi, Siyaset Bilimi ve Kamu Yönetimi Bölümü, Siyaset ve Sosyal Bilimler ABD, korkmazhatun@hotmail.com

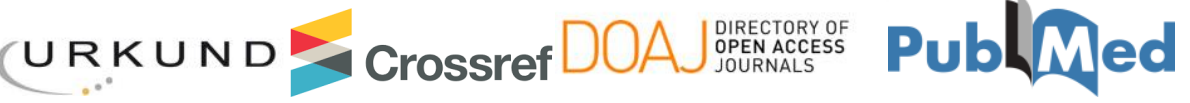




\section{Giriş}

Yerel yönetimler, geçmişten bu yana iki temel işleve sahiptirler. Birincisi, ulaşım, imar, çevre ve temizlik gibi kentsel odaklı hizmetler, ikincisi, siyasi bir organ olarak halkın politik eğilimlerini ve tercihlerini temsil etme hizmetidir. Ancak günümüzde, yerel yönetimler siyasi bir organ olmaktan ziyade, kentsel odaklı hizmetlerle daha çok gündeme gelir olmuşlardır ve yerel yönetimlerin başarısı, adeta kentsel hizmetlerle paralel olarak değerlendirilir olmuștur. Bu durum, yerel yönetimleri siyasi bir aktör olma konusunda atıl duruma düşürmüş ve etkinlik, ekonomiklik ve verimlilik konusuna daha çok eğilmeye sevk etmiştir.

1970'li yıllarda refah devleti anlayışının sorgulanmaya başlanması, kamu yönetiminde yeni model arayışlarını beraberinde getirmiştir. Bu doğrultuda merkezi ve yerel yönetimler, "etkinlik, verimlilik, ekonomiklik, rekabet, projecilik, girişimcilik" gibi işletme yönetimi değerleri etrafında yeniden yapılandırılmaya başlanmıştır (Aydınlı ve Aydın, 2004).

Öte yandan, dünyada bugün gelinen noktada demokrasi kavramı yönetimlerin olmazsa olmaz unsuru olarak bilinmektedir. Yeni kamu yönetimi anlayışında demokrasi konusunda yerele çok büyük değer ve görev atfedilmektedir. Zira, geçmişten bugüne yerel yönetimler, demokrasinin yerleşmesinde başat faktör ve siyasetin beşiği olarak çok önemli bir yere sahip olmuşlardır.

Her ne kadar etkinlik ve demokrasi kavramları bugün yerel yönetimlerin vazgeçilmez unsurları olsa da, bu iki kavramın bir arada eksiksiz şekilde uygulanması pek mümkün değildir. Etkinlik, ekonomiklik ve verimlilik kavramları, nispeten büyük ölçekli yerel idareleri işaret ederken, demokrasiyi merkeze alan anlayış haliyle küçük ölçeği işaret etmektedir. Zira, kamu hizmetlerinin etkili sunumu, kaynak israfının önlenmesi, koordinasyon ve ölçek ekonomilerinin sağlanmasının, büyük ölçekli yerel yönetimlerde daha başarılı sonuçlar verdiği düşünülmektedir. Burada asıl sorun, ölçeğin ne kadar büyük olması gerektiğidir. Ölçeğin büyüklüğü ve etkinlik her zaman paralel midir? Optimal ölçek her zaman büyük ölçek anlamına mı gelmektedir? Büyük ölçekle ölçek ekonomilerinin sağlanabileceği ve kamu hizmetlerinin daha etkin sunulabileceği savı her coğrafya için geçerli midir? Bu soruların cevaplanabilmesi büyük ölçek tartışmalarında önem arz etmektedir.

Öte yandan, demokratik yönetimin temelinde, halkın karar alma mekanizmasında söz sahibi olması için hizmetlerin halka en yakın birim tarafından sunulması yer almaktadır. Bu durum, küçük ölçekli birimlerin daha demokratik yönetim tarzına nispeten daha yakın durduğunu göstermektedir.

Kamu hizmetlerinin sunumunda etkinlik kavramına dayalı olarak büyük ölçekten yana fikir beyan edenlere göre daha önce de ifade edildiği gibi büyük ölçekte ölçek ekonomileri uygulanabilecek ve böylelikle kaynakların adil ve verimli dağılımı söz konusu olabilecektir. Ayrıca hizmetlerin planlı ve koordineli bir şekilde sunulması için büyük ölçekli bir yönetim kaçınılmazdır. Ayrıca büyük ölçek demokrasi karşısına alan bir uygulama değildir. Küçük ölçek demokratik katılım açısından avantajı ılsa da etkinlik için büyük ölçeğe gerek duyulmaktadır. Öte yandan demokrasi salt ölçekle açıklanabilecek bir durumdan öte, yerel yönetimlerin kurumsal özellikleri, mali ve idari özerklik ve yetkiyi kullanma kabiliyetine göre şekillenen bir olgudur.

$\mathrm{Bu}$ çalışmada, yerel yönetimlerin hizmet sunumunda etkinliği ve demokrasi çelişkisi, ölçek sorunsalı çerçevesinde, ölçek büyüdükçe hizmet sunumu daha etkin ve verimli hale gelir argümanından hareketle dünya ve Türkiye'deki örnekleri ile karşılaştırmalı olarak açıklanmaya çalışılacaktır.

\section{Demokrasi ve Yerel Yönetimlerde Ölçek}

Çok eski çağlardan beri demokrasi ve yerel arasında sıkı bir ilişki kurulmuştur. Yerel yönetimler, demokrasinin beşiği ve uygulama okulu olarak görülmektedir. Günümüz dünyasında, temsili demokrasinin işleyişinde ortaya çıkan aksaklıklar, toplumları yeni demokrasi arayışlarına yöneltmiş ve katılımcı demokrasi tartışmaları gündeme gelmiştir. Katılımcı demokrasinin temelinde ise yerel katılım yer almaktadır (Çukurçayır, 2000: 38; Gökçe, 
2015). Rousseau, Platon ve Aristo gibi düşünürler küçük siyasi birimlerden yana olmuşlardır. Bu düşünürlerin teorileri temsili demokrasiden ziyade doğrudan demokrasiye ilișkin olsa da temel ilke yönetimin halka yaklaşmasının, halkın etkisinin ve katılımını artıracağıdır (Rydergard, 2012: 5). Diğer bir ifade ile temel ilke, kamusal sorumlulukların vatandaşa fiziksel olarak en yakın ve toplumun çıkarını temsil eden birimler tarafından yerine getirilmesidir (Koyuncu ve Sertesen, 2012: 4-5).

Bu ilke, iyi kamu hizmetini tanımlama yerine, "demokratik açıdan iyi" olanın üzerinde yoğunlaşmaktadır (Koyuncu ve Sertesen, 2012: 4-5). Etkinlik, verimlilik ve ekonomiklik kavramlarından beslenen yeni kamu yönetimi anlayışının öngördüğü "yerel” ile "demokratik açıdan iyi" ilkesi üzerine temellendirilmiş "yerel" in çakıştığı nokta tam da burasıdır. Zira, etkinlik, ekonomiklik ve verimlilik kavramları, nispeten büyük ölçekli yerel idareleri işaret ederken, demokrasiyi merkeze alan anlayış haliyle küçük ölçeği işaret etmektedir. Yukarıda da ifade edildiği gibi, demokrasiyi merkeze alan anlayışa göre kamusal sorunluluklar fiziksel olarak halka en yakın birimler tarafından yerine getirilmelidir.

Günümüzde yerelleşme yalnız yerel demokrasinin sağlanması açısından değil, merkezi yönetimin gücünün sınırlanması açısından da önem arz etmektedir. Salt merkezi yönetimin hâkim olduğu bir düzende halkın yönetime katılımı güçleşerek demokrasi sekteye uğrayabilmektedir. Bu noktada yerel yönetimler, merkezle halk arasında bir köprü olarak düşünülebilir.

Yerel yönetimlerin varlığı, bir çok açıdan demokrasinin yerleşmesine katkı sağlamaktadır. Ancak bu durum, yerel ne kadar güçlenirse veya merkez ne kadar zayıflatılırsa demokrasi o kadar iyi yerleşir anlamına gelmemektedir. Yerele devredilen gücün, yerel elitler tarafından ele geçirilmesi ve küçük birimlerin sınırlı kapasitelerinden dolayı, yerel planlama ve karar alma sürecinde daha az etkiye sahip olması gibi olumsuz durumlar ortaya çıkabilir. Başka bir ifade ile küçük yerleșim birimlerinde daha yüksek katılım olabilir, ancak bu kentteki katılımcılar, daha küçük bir etki alanına sahip olacaklardır (Bayraktar, 2014).

Daha verimli, etkili ve ekonomik hizmet üretmek için uygulanan ölçek ekonomisi, optimal ölçek veya büyük ölçek uygulamaları, hizmet alanının coğrafi olarak büyümesine neden olacaktır ve neticede kararların alınmasındaki demokratik temsil ve katılım güçleşecektir. Zira hizmet kapsamının genişlemesi, karar organlarıyla halk arasındaki mesafenin artmasına ve karar alıcıların tabandan bağımsızlaşmasına yol açacaktır. Ayrıca, büyük ölçekte, daha çok kaynağa ve daha geniş yetkiye sahip yöneticiler, zamanla merkezi hükümetin statüsüne bürünerek yerelin merkezi olmaya başlayacaktır (Bayraktar, 2014).

Yerel yönetimlerde demokrasiyi temel alan ve büyük ölçek savının karşısında yer alan tarafların iddia ettiği diğer bir nokta ise, büyük ölçeklerde bazı yerel toplulukların kimlik kaybına uğrayabileceğidir. Bu sava göre, küçük ölçeklerde yerel topluluklar kimliklerini koruyabilecek ve yerel siyasete katılımları da daha güçlü olacaktır (Zengin, 2014: 108-114).

Bugün gelinen noktada, demokrasi ve etkinlik kavramları çok boyutlu yönden ele alınmaktadır. Etkinlik kavramı, amaç ve hedeflere odaklanılarak, girdi çıktı ilişsisini tanımlamayı esas alırken, demokrasi kavramı halkın yönetime katılımını ve memnuniyetini esas almaktadır. Halkın yönetime katılarak taleplerinin yönetime yansımasının, etkinliği azalttığı yönünde ve etkinliği sağlama noktasında demokrasinin işleyişinin sekteye uğrayabileceği yönünde yaygın görüşler mevcuttur (Kesgin, 2015: 159-160).

Etkinlik ve demokrasi kavramları, kamu yönetiminde ve kamu yönetimlerinin minyatürü olan yerel yönetimlerde son dönemlerde çok sık tartışılmaya başlanmıştır. Özellikle íki kavramın birbirine zıt mı veya ikisinin de yerel veya merkezi idarelerin olmazsa olmaz parçaları mı olduğu üzerinde sıklıkla durulmaya başlanmıştır.

Dünyanın geldiği noktada etkinlik ve demokrasi kavramlarının yönetimler açısından olmazsa olmaz bir ilke olduğu konusunda bütün tarafların mutabakat vardığı görülmektedir. Mutabakata varılmayan nokta ise, sözü 
edilen kavramlardan hangisinin diğerine tercih edileceğidir. Zira, iki kavramın da nüveleri gereği bir arada eksiksiz işleyişinin mümkün görünmediği yukarıda belirtilmiştir. $\mathrm{Bu}$ kavramlardan demokrasi, toplumsal uzlaşmanın bir sirayeti olarak ortaya çıkarken, öte yandan toplumsal amaca hizmet etmesi için kamu yönetimlerine anlam kazandırmak demokrasi ile mümkün olmuştur (Kesgin, 2015: 159-160). Aynı şekilde etkinlik kavramı, özellikle 1980'lerden sonra daha önce de ifade edildiği gibi yeni kamu yönetimi anlayışının da mihenk taşlarından birini oluşturmaya başlamıştır.

\section{Etkinlik, Verimlilik ve Yerel Yönetimlerde Ölçek}

Yönetimde etkinlik ve verimlilik kavramları, ilk olarak işletme yönetiminde ortaya çıkmıştır. 1980'lerden itibaren neoliberal politikaların tekrar canlanmasıly kamu yönetiminde kar, verimlilik, etkinlik kavramları sıkça gündeme gelir olmuş ve özel sektör mantığının kamu sektörüne uyarlanması kamu sektörünü verimsizlikten kurtaracak bir yol olarak görülmeye başlanmıştır (Eryılmaz, 2004. 5455). Bu değişimlerin kamu yönetimine ve yerel yönetimlere sirayeti, yeni model ve ölçek arayışlarında görülmüştür.

Yerel yönetimlerde etkinlik, verimlilik ve ölçek kavramları akla ilk olarak "Optimal Ölçek" kavramını getirmektedir. Optimal ölçek kavramının ne olduğu konusunda henüz bir mutabakata varılmamıştır. Kavramın, birçok kişi tarafından farklı anlamlarda tanımı yapılmaktadır. Örneğin Tortop, optimal ölçek kavramını bir yerel yönetim birimi olan belediyeler açısından, "belediyenin kamu hizmetlerini etkin bir şekilde sunulmasını sağlayacak nüfusa ve alana sahip olması" olarak tanımlamaktadır (Tortop, 1995: 21). Capello ve Roberto'ya göre optimal ölçek, etkin ve verimli büyüklük anlamına gelmektedir ve yerleşim yapısının ekonomik yönünü ifade etmektedir (Capello and Roberto, 2000:1479). Bu tanımlardan yola çıkarak optimal ölçeği, kent yönetiminde en uygun büyüklük olarak özetleyebiliriz.
Burada temel problem, kentler için optimal ölçeğin, başka bir ifade ile en uygun kent büyüklüğünün ne olması ve nasıl olmasıdır. Araştırmacılara göre, optimal kent büyüklüğünün nasıl olması gerektiğini belirlemek önemli ve zor bir konudur. Özellikle 1970'lerden sonra tartışma konusu olan optimal kent büyüklüğü ile ilgili ekonomik literatür, tutarsız ve kompleks bir yapıdadır (Keleş, 2004: 46; Tsidell, 1975: 61; Çimen, 2013: 343). Örneğin, kentin nüfus ve yüz ölçümünde belirli bir orana kadar meydana gelen yoğunluk ve genişlemenin, kentsel hizmetlerin maliyetini azalttığı, buna rağmen gereğinden fazla büyüyen kentlerin kentsel hizmet maliyetlerini arttırdığı kabul edilmektedir (Keleş, 2004: 46-47).

Bu çerçevede dikkate alınması gereken konu genel refahı en üst seviyede sağlayacak bir optimal kent büyüklüğünün sağlanmasıdır. Çünkü kentlerin tarihsel gelişimi, kent büyüklüğü, yaşam kalitesi ve iş verimliliği arasında güçlü bir ilişki vardır ve kent büyüklüğü toplumsal refahın sağlanmasında önemli bir belirleyici etkendir (Getz, 1979: 197). Bundan şu sonuca varılabilir: Kent yönetimi için en uygun büyüklük, nüfus, sosyal, ekonomik ve siyasal nedenlerle ülkeden ülkeye, bölgeden bölgeye değişiklik gösterebilmektedir.

Kent büyüklüğü veya optimal kent ölçümü hesaplanırken ölçek ekonomisi teorilerinden faydalanılmaktadır. Yerel yönetimlerde ölçek ekonomisi, hizmetin marjinal maliyeti ile hizmetin görüleceği alan ve nüfus miktarı arasındaki ilişki ile açıklanmaktadır. Buna göre, marjinal maliyeti hizmetin sunulduğu alan ve nüfus ile ters orantılı olarak optimum noktaya gelinceye kadar düşmekte, bu noktadan sonra meydana gelebilecek alan ve nüfus artışı karşısında ise marjinal maliyet yükselmeye başlamaktadır (Nadaroğlu ve Keleş, 1991: 49; Şafaklı, Güryay, 2005: 168).

Bazı görüşlere göre yerel yönetimlere ölçek ekonomisinin yaklaşımını uyarladığımızda, hizmet ölçeği büyüdükçe altyapı yatırımlarının yapılmasında, kentsel hizmetlerin sunulmasında ve kurumsal işleyiş açısından daha ucuz ve daha kaliteli bir hizmet sunumu sağlanabilmektedir. Bu anlamda küçük ölçekli 
idari birimlerin kentsel hizmetlerin sunumunu parça parça kendilerinin vermelerindense tek bir elden, geniş bir ölçekten, daha gelişmiş bir pazarlık gücü, daha uzman personel ve daha gelişmiş bir teknoloji kullanarak sunulmasının daha kaliteli ve verimli olduğu iddia edilmektedir. (Bayraktar, 2014).

Ölçek büyümesi ile sağlanacak avantajlardan biri de üretim ve teknoloji arasındaki kurulabilecek ilişkidir. Buna göre, küçük ölçekli yerel yönetimler kamusal hizmet sunumunu küçük miktar çerçevesinde gerçekleștireceklerdir. Böyle durumlarda hizmet sunumunda gelişmiş teknolojilerin kullanımı ekonomik ve gerekli olmayacaktır. Çünkü gelişmiş teknolojiler, büyük çapta üretim yaparak birim başına maliyeti düşürüp ve önemli tasarruflar sağlayabilmektedirler. Dolayısıyla, gelişmiş teknolojilere küçük ölçekli yerel idareler yeterli iş yükünü sağlayamayacaktır. Bu anlamda küçük bir belediyenin gelişmiş teknolojik bir aracı alması kaynak israfına neden olacaktır (Topal, 2011: 372). Ayrıca ölçeğin büyümesi ile yere idareler daha çok kaynağa sahip olacakları için personele daha yüksek ücret ödeyebilme gücüne sahip olacaklardır. Bu da daha kalifiye seçilmiş ve atanmış personeller için cezbedici bir durum oluşturacaktır.

Başka bir açıdan, optimal ölçekte bulunmayan yerel idareler, başta nepotizm olmak üzere, personel ve maddi kaynak sorunları ile karşı karşıyadırlar (Özgür, 2002: 295). Büyük ölçeğe yöneltilen karşı savlar çoğunlukla demokrasinin sekteye uğrayacağı endişesi etrafında öbekleşmişlerdir. Ancak, büyük ölçeği savlayanlara göre, yerele devredilen gücün yerel elitler tarafından ele geçirilmesi ve küçük ölçekte yüksek katılıma rağmen etki alanının daralma olasılığı yüksektir. Bu görüş, "Yerel ne kadar küçük ölçekte olursa demokrasi o kadar iyi yerleşir" savına karşı çıkmaktadır (Bayraktar, 2014).
"Yerel yönetimlerde etkinlik ve verimliliği sağlamanın yolunun büyük ölçekli idarelerden geçtiği" savına göre, özetle:

- Nitelikli iş gücü ve teknik personel istihdamı ile verimlilik sağlanabilecektir.

- Kaynakların koordineli, verimli, adil ve etkin kullanımı sağlanabilecektir.

- Etki alanı daha geniş bir siyasal katııım söz konusu olabilecektir.

- Ölçek ekonomileri uygulanabilecektir.

- İmar, planlama, ulaşım gibi temel hizmetler daha koordineli hale gelecektir.

Buna karşılık, daha etkili, ekonomik ve verimli hizmet sunumu için büyültülen ölçek, demokratik katılım ve temsil imkânlarını zorlaştırabilir. Zira hizmet sınırlarının genişlemesi demek, karar organları ve seçmen arasındaki mesafenin de genişlemesi anlamına gelmektedir. Böylelikle karar alıcılar tabandan bağımsız, büyük ölçekte devasa boyutlarda kaynak ve yetkileri ile yerelin merkezi olarak ișlev göremeye başlayacaktır. Diğer bir deyişle merkezi idareye atfedilen birçok dezavantaj bu kez, büyük ölçekte yerelin merkezi olarak işlev gören idarelerde görülmeye başlanacaktır.

\section{Dünya ve Türkiye'den Örnekler}

II. Dünya Savaşı'ndan sonra dünya genelinde yerel yönetimler evrim geçirmeye başlamış ve 1960'lı yıllardan sonra, yerel yönetimlerle ilgili model ve ölçek arayışları hız kazanmıștır. Yerel yönetimler ile ilgili model ve ölçek arayışları dünya genelinde ağılıklı olarak ölçek büyütme yönünde gerçekleşmiștir. Aşağıdaki tablodan da görüldüğü gibi 19502005 yılları arasında, birçok ülkede en önemli yerel yönetim birimi olan belediyelerin sayıları azalmıştır. 
Tablo.1. Bazı Ülkelerde Belediye Sayılarındaki Değişim

\begin{tabular}{|c|c|c|c|c|c|}
\hline Ülke & 1950 & 1992 & $\begin{array}{l}\text { 1950-1992 Değişim } \\
\text { (\%) }\end{array}$ & 2005 & $\begin{array}{l}\text { 1992-2005 } \\
\text { Değișim (\%) }\end{array}$ \\
\hline İsveç & 2.281 & 286 & (-) 87,5 & 290 & $(+) 1,4$ \\
\hline Belçika & 2.269 & 589 & (-) 77,9 & 600 & $(+) 1,9$ \\
\hline İngiltere & 2.028 & 484 & $(-) 76,1$ & 467 & $(-) 3,5$ \\
\hline Avusturya & 3.999 & 2.301 & (-) 42,5 & 2.400 & $(+) 4,3$ \\
\hline Norveç & 744 & 439 & (-) 41,0 & 440 & $(+) 0,2$ \\
\hline Hollanda & 1015 & 647 & $(-) 36,3$ & 647 & 0 \\
\hline İspanya & 9.214 & 8.082 & (-) 12,3 & 8.109 & $(+) 0,3$ \\
\hline Fransa & 38.814 & 36.763 & $(-) 5,3$ & 37.000 & $(+) 0,6$ \\
\hline Yunanistan & 5.959 & 5.922 & $(-) 0,6$ & 1.031 & (-) 82,6 \\
\hline Bulgaristan & 2.178 & 255 & (-) 88,3 & 264 & (+) 3,5 \\
\hline İtalya & 7.781 & 8.100 & $(+) 4,1$ & 8.000 & $(-) 1,2$ \\
\hline Türkiye & 628 & 2.270 & (+) 261,5 & 3.225 & (+) 42,1 \\
\hline
\end{tabular}

Kaynak: (Arıkboğa, 2007: 4).

Tabloya dayalı olarak dünya genelinde bir çok ülkede belediyelerde ölçek büyütme yoluna gidilmesinin ardında yatan sebep, belediyeler için optimal ölçeğin yeni kamu yönetimi anlayışının temel parametreleri olan etkinlik, verimlilik ve ekonomiklik kavramlarına hizmet ettiği düşüncesidir. Örneğin, İtalya'daki belediyeler üzerine İtalya İçişleri Bakanlığı'nın 1985 yılında yaptığı bir çalışma ile belediyelerin nüfus büyüklükleri ile kişi başına maliyet arasında "u" eğrisi biçiminde bir ilişki görülmüș ve buna paralel nüfusu 5000'in altında olan belediyelerde kişi başına yapılan harcamanın yüksek çıktığı, 5.000 sınırına yaklaştıkça bu düzeyin düştüğünü, fakat 5.000 sınırından sonra bu düzeyin tekrar yükselmeye başladığı görülmüştür (MiGM, 1995:14-17). Bu örnekten şu sonuç çıkarılabilir: Ölçek ve maliyet mutlak bir ters orantı sergilememektedir. "Ölçek büyüdükçe maliyet düşer" argümanı optimal ölçeğe eri- şinceye kadar geçerlidir. Optimal ölçek, yani en uygun kent ölçeği yakalandıktan sonra ölçeğin büyümeye devam etmesi, maliyeti de büyültür.

Birleşik Krallık, Danimarka, Litvanya, Macaristan, gibi ülkelerde belediye büyüklükleri 50.000'in üstündedir. Bu ülkelerde büyük ölçek benimsenmiştir. Fransa'da belediye sayısı komşu ülkelerle kıyaslandığında oldukça yüksek ve dağınık bir görüntüye sahiptir. Belediyelerin \%9o'ından fazlasının nüfusu 2000 'in altındadır. Nüfusu 100.000 'in üzerindeki belediye oranı \%2'dir. Fransa nüfusunun yaklaşık yarısı bu \%2'lik dilime giren kısımda ikamet etmektedir. 2000'in altında nüfusu olan belediyelerde sürekli ikamet eden nüfus bulunmamaktadır. Bu durumun sebebi Fransızların belediyelerine olan güçlü bağlılığıdır. Bu bağlılıktan dolayı belediyelerin birleștirilmesi yönünde atılan adımlar sonuç verme- 
miştir. Bu bağlılığın ardına, belediye kurulușunun eskiliği, belediye yerleșim yerinde kurulan ilişkilerin niteliği, belediye sakinlerinin ile belediye seçilmişleri ile daha kolay ve daha etkili şekilde iletişim kurabilmeleri vardır (Şengül, 2014: 82).

Dünya genelinde olduğu gibi Türkiye'de de íkinci Dünya Savaşı'ndan sonra yerel yönetimlerde model ve ölçek düzenlemelerine gidilmiştir. 1950-1992 yıllarında Türkiye'deki belediye sayısı Tablo 1'de de görüldüğü gibi \%261 artmıştır. Ancak Türkiye'deki belediye sayılarını Avrupa ülkeleri ile karşılaştırırken köy sayılarını da dikkate almak gerekir. Çünkü Türkiye'de küçük ölçekli yerleşmelerde belediye yerine köy yerel yönetimi bulunmaktadır. Avrupa'daki çoğu ülkede ise, köybelediye ayrımı yoktur (Arıkboğa, 2007: 4).

Türkiye'de özellikle 1980 sonrasında il, ilçe ve belediye sayısının arttığı görülmektedir. Örneğin, 1985 yılında 1703 olan belediye sayısı, 1988'de1925'e, 1992'de 2270'e, 1997'de 2801'e, 2000'de 3200'e ve 2005'de ise 3250'ye ulaşmıştır (Keleş, 2006: 204). Özellikle seçim dönemlerinde verilen vaatler sonucunda bele- diye sayılarında önemli artışlar olmuştur. Birçok suni il, ilçe ve belediye birimi siyasi vaatler neticesinde kurulmuştur. Yerel idarelerin sayılarındaki bu artış, ekonomik gerekçelerden ziyade siyasi gerekçelerle açıklanabilmektedir (Akdede ve Acartürk, 2005: 8). Bu yerleşim yerleri, hizmet sunumunda yeterli performansı gösterememișlerdir. Kimi zaman kurulan suni yönetsel birimler, var olan yönetsel birimin siyasi kaygılarla parçalanması neticesinde oluşturulmuşlardır. Bunun sonucunda bir yerleşim yerinde birden fazla etkili, ekonomik ve verimli olmayan parçalı yapılar ortaya çıkmıştır (Çınar, Duru, Çiner ve Zengin, 2013). Bu artışın özellikle 2012 yılında yürürlüğe gire 6360 sayılı "On Dört İlde Büyükşehir Belediyesi ve Yirmi Altı ilçe Kurulması ile Bazı Kanun ve Kanun Hükmünde Kararnamelerde Değişiklik Yapılmasına Dair Kanun" kanun ile birlikte düşüșe geçtiği görülmektedir (Göküş ve Alptürker: 2016: 73).

Aşağıdaki tabloda 6360 sayılı Kanun öncesi ve sonrası yerel yönetim sayıları gösterilmiştir.

Tablo2. 6360 Sayılı Kanun öncesi ve Sonrası Yerel Yönetim Sayıları

\begin{tabular}{|l|l|l|l|l|}
\hline $\begin{array}{l}\text { Yerel Yönetim Birimleri } \\
\text { (YYB) }\end{array}$ & $\begin{array}{l}6360 \text { Öncesi } \\
\text { Toplam YYB }\end{array}$ & $\begin{array}{l}6360 \prime l a \\
\text { Kurulan YYB }\end{array}$ & $\begin{array}{l}\text { 6360'la Kaldırılan } \\
\text { YYB }\end{array}$ & $\begin{array}{l}\text { 6360 Sonrası } \\
\text { Toplam } \\
\text { YYB }\end{array}$ \\
\hline Büyük Şehir Belediyesi & 16 & 14 & - & 30 \\
\hline $\begin{array}{l}\text { Büyük Şehir Illçe } \\
\text { Belediyesi }\end{array}$ & 143 & 25 & - & 519 \\
\hline İl belediyesi & 65 & - & 14 & 51 \\
\hline İlçe belediyesi & 749 & 2 & 349 & 416 \\
\hline Belde Belediyesi & 1.977 & - & 1.635 & 342 \\
\hline Toplam Belediye & 2.950 & 41 & 1.998 & 1.358 \\
\hline il Özel Idaresi & 81 & - & 30 & 51 \\
\hline Köy & 34.395 & - & 16.561 & 17.84 \\
\hline Mahalle & 19.103 & 17.637 & - & 36.740 \\
\hline
\end{tabular}

Kaynak: (Adıgüzel, 2012: 160). 
Tbalo1 ve Tbalo2 arasında bir karşılaştırma yaparsak, Türkiye'de Diğer ülkelere göre 1950 yılından 2005 yılına kadar yerel yönetimlerde mütemadiyen bir artış gözlemlenmektedir. Yerel yönetim sayılarında düşüş için atılan ilk önemli adım 2008 yılında yürürlüğe giren 5747 sayılı kanun ile olmuştur. Ardından 6360 sayılı Kanun ile küçük ölçekli yerel yönetim sayılarında önemli düşüşün gerçekleştiği söylenebilir.

Türkiye'de yerel yönetimlerde ölçek ile ilgili çalışmalar 2000'lerden sonra yoğunlaşmıştır. 1580 sayılı kanun, yeni belediye kurulabilmesi için 2000 nüfus şartı öngörmekteydi. Bu eşiğin oldukça küçük olması, belediye sayılarının fazla ve küçük ölçekte olmasına yol açmıştır. 2005 yılında yürürlüğe giren 5393 sayılı Belediye Kanunu, 2000 eşiğini 5000'e çıkarmıştır. Bu adımla yerel yönetimlerde büyük ölçek politikasının izlenmeye başlandığını görmekteyiz (Urhan, 2007: 90).

Türkiye'de bu yönde yapılan araştırmalara göre, belediyelerde kişi başına düşen personel harcaması, nüfusu 5000'in altında olan belediyelerde diğer belediyelere göre, daha yüksek çıkmaktadır. Ancak, belli bir büyüklüğe ulaştıktan sonra, bu doğru orantının da tersine döneceği beklenmektedir. Özetle, yerel yönetimlerin nüfusu belirli bir seviyeye kadar etkinlikleri ile doğru orantılıdır denilebilir (MiGM, 1995: 14-17).

Türkiye'de ölçek ile ilgili yapılan çalışmalara tekrar döndüğümüzde, Anayasanın 127. maddesinin 3. Fıkrasında yer alan "Büyük yerleşim merkezleri için özel yerleşim birimleri getirilebilir." Ifadesine dayanılarak, 1984 yılında 3030 sayılı Büyükşehir Kanunu yürürlüğe girmiştir. Kanun ilk olarak Ankara ve i̇stanbul'da uygulamaya konulmuştur (Atmaca, 2013: 169-170). 3030 sayılı kanun, büyükşehir kurulabilmesi için 300.000 nüfus şartını getirmiştir. Ayrıca büyükşehir kurulabilmesi için büyükşehir sınırları içerisinde birden fazla ilçe olması gerekmekteydi. Daha sonra 504 sayılı KHK il büyükşehir belediye sınırları içinde birden fazla ilçe olmayan yerler için farklı uygulamaya gidilmiş ve buralarda yeni ilçe oluşumu yerine alt kademe belediye uygulaması getirilmiştir. Bu değişikliğin sebebi, yeni ilçelerin oluşumuyla gelen maliyetlerden kaçınmak olarak yorumlanmıştır (Şengül, 2016: 126). 2004 yılında 5216 sayılı kanunun yürürlüğe girmesi ile 3030 sayılı kanun yürüklükten kaldırılmıştır. 5216 sayılı kanunun 6360 sayılı kanun ile değiştirilen maddesine göre büyükşehir olma koşulu 750.000'den fazla nüfusa sahip olmak olarak belirlenmiştir. 5216 sayılı kanunda yapılan değişikliklere göre yerelde büyük ölçeğin benimsendiği, ölçek ekonomilerinin uygulanmaya başlandığı açıkça ortaya çıkmıştır.

Yürürlükte olan 5216 sayılı Kanun'a önemli müdahalelerden biri 2008 yılında yürürlüğe giren 5747 sayılı Kanun'la olmuştur. Bu kanunla, ilk kademe belediyesi uygulamasına son verilmiş ve büyükşehir belediyeleri iki kademeli sisteme (büyükşehir belediyesi + Büyükşehir ilçe belediyesi) yıllar sonra geri dönmüştür. Kanunun yürürlüğe girdiği 29 Mart 2009 Yerel Yönetim Seçimleri'yle birlikte on altı büyükşehir belediyesi sınırları içinde yer alan 240 belde belediyesi mahalleye dönüştürülerek kapatılmıştır. Bu kanunun ile yapılan bir diğer önemli değişiklik ise nüfusu 2.000'in altında olduğu tespit edilen 862 belde belediyesinin, köye dönüştürülerek kapatılması düzenlemesidir (Zengin, 2014: 101). 5747 sayılı Kanun kapsamında yapılan değişiklikleri büyük ölçek lehine olarak yorumlamak mümkündür. Zira 5747 sayılı Kanun ile yapılan değişiklikler, 5216 sayılı Kanun'a yapılan bir diğer önemli müdahale olarak değerlendirilen 6360 sayılı kanun ile yapılan değişikliklerin ilk adımı görüntüsünü vermektedir.

Türkiye'de yerel yönetimlerde model ve ölçek çalışmaları ile ilgili en köklü değişikliklerden biri 6360 sayılı Kanun ile olmuştur. Bu kanun çerçevesinde 14 yeni büyükşehir belediyesi kurulmasıyla Türkiye'deki toplam büyükșehir belediye sayısı 30'a yükselmiştir. Kanun ile birlikte, bütün büyükşehir belediye sınırları il mülki sınırı olarak kabul belirlenmiş, ilçe belediye sınırları ilçe mülki sınırı olarak belirlenmiştir. Ayrıca kanun çerçevesinde, Büyükșehir Belediyesi olan illere bağlı ilçelerin mülki sınırları içerisinde yer alan köy ve beldelerin tüzel kişilikleri kaldırılmıştır. Tüzel kişilikleri kaldırılan köy ve beldeler, belde ismiyle tek mahalle olarak bağlı bulundukları ilçenin belediyesine katılmıştır. Büyükşehir 
belediyesi bulunan 30 ilde il özel idarelerinin tüzel kişiliği kaldırılmıștır. il belediyesi bulunan 51 ilde ise il özel idarelerinin tüzel kişiliği devam etmektedir. Kanunun bazı maddeleri yayımı tarihinde diğer maddeleri ise 30 Mart 2014 tarihinde yapılan mahalli idareler genel seçimi ile birlikte yürürlüğe girmiştir. (TBB, 2014: 17-20). Büyükșehir belediyelerinin bulunduğu illerde Yatırım İzleme ve Koordinasyon Başkanlığı (YIKOB) kurulmuştur. YíKOB'ların Büyükşehir olan illerde kaldırılan il özel idarelerinden doğacak boşluğu doldurmak amacı ile kurulduğu düşünülmektedir. Zira daha önce il özel idarelerinin yetki alanında olan birçok görev ve sorumluluk 6360 sayılı kanun ile YiKOB'lara devredilmiştir (Önez Çetin, 2015: 256). YíKOB'ların kurulması, yeni kurulan büyükşehir belediyelerinin ortaya çıkacak idari boşluğu doldurma konusunda yeterli görülmediğinin kanıtıdır. Çünkü YiKOB'un 6360 sayılı Kanun'da sayılan görev, yetki ve sorumlulukları incelendiğinde "alternatif il genel yönetimi” olduğu düşünülmekte ve İçişleri Bakanlığı bünyesinde ortaya çıktığı için de il genel idaresinin içini boșalttığı belirtilmektedir (Güler, 2012b: 104). Ayrıca bu alternatif birimin sevk ve idaresinin illerde valilik ve ilçelerde kaymakamlar tarafından yerine getirilecek olması, mülki idare amirleri ile belediyeler arasında anlaşmazlıkların ortaya çıkma ihtimalini doğurmaktadır (Adıgüzel, 2012: 172-173).

6360 sayılı kanun ile yapılan bu değişiklikler, uzun zaman kamuoyunun gündemini meşgul etmiş ve birçok tartışmaya sebebiyet vermiştir. Kanunun uygulanmasını doğru bulan çevrelere göre, kaynakların optimal dağılımı gerçekleștirilecek ve yıllardır merkezi idareden gelen kaynakla hizmet üretmeye çalışan köy modeli tarihe karışacaktır. Köylünün içme suyu, yol vs., gibi hizmetlerde yaşadığı mağduriyet, yeni kanun ile büyükşehir belediyesi tarafından ilin genelinin planlanarak koordinasyonu içerisinde çözüme kavuşturulacaktır (Doğru, 2013). Zira, yönetim kademelerinin ve birimlerinin sayılarının azaltılması ve optimal yönetim alanına ulaşılması son dönemlerde rağbet gören idari reformlardan bir tanesidir. Böylelikle en ekonomik düzeyde hizmet ve yatırımların sağlanmasına ve "alan ve nüfus optimalitesi" elde edilmeye çalışılmaktadır (Parlak, 2013).

Bunun yanında kanuna yapılan eleştirilere göre mülki sınırlar, mahalli hizmetler için uygun ölçek değildir. Sınırları siyasi ve idari ölçütler ile belirlenen mülki yönetim ile sınırları yerel nitelikli hizmetler ölçütüne göre belirlenen mahalli yönetimin hizmet ve yönetim ölçütleri birbirinden farklıdır. Kentsel alan olarak kurulan belediyeler, kırsal alanda başarılı hizmetler vermeyebilirler (Çukurçayır, 2014; Çelikyay, 2014: 18). Ayrıca bu çevrelere göre kapatılan küçük ölçekli birimlerde aidiyet duygusu ve manevi değerlerin zarar görme ihtimali yüksektir ve kapatılan birimlerle birlikte bu birimlerin karar organları da kapatılacaktır ve halk katılımı önemli ölçüde zedelenecektir (Adıgüzel, 2012: 161).

\section{Sonuç}

Yerel yönetimlerde model tartışmaları genel olarak iki ana eksen üzerinde şekillenmektedir. Bunlardan birincisi ölçek düzenlemeleri sonucu, kamusal hizmetlerin etkin ve verimli şekilde yürütülüp yürütülmediğidir. İkinci eksen ise reform ya da politika üretme süreçlerinde demokratik katılım mekanizmalarına ne ölçüde dayanılıp dayanılmadığıdır. Başka bir ifade ile tartışmalar "etkinlik" ve “demokrasi” eksenleri üzerinden yürümektedir. Bu iki kavram, bugün yönetimlerin olmazsa olmaz iki unsuru olarak kabul edilmektedir. Ancak, iki kavramın da nüveleri gereği bir arada eksiksiz işleyişi mümkün görünmemektedir. Çünkü etkinlik kavramı, büyük ölçekli yerel idareleri işaret ederken, demokrasiyi merkeze alan anlayış haliyle küçük ölçeği işaret etmektedir. Zira demokrasinin temelinde kamusal sorunluluklar fiziksel olarak halka en yakın birimler tarafından yerine getirilmelidir anlayışı yer almaktadır. Öyle ki, 1992 Avrupa Birliği Maastricht Anlaşması'nda yer verilen "Subsidiarity ilkesi" ne göre yerel topluluğa hizmet sunumunda alt düzey yönetimlere öncelik tanınmalıdır. 
Ayrıca optimal büyüklüğün ne olması gerektiği sorusu tek bir cevapla açıklanabilecek bir durum değildir. Zira, optimal büyüklük hizmetin türü ve niteliğine göre değişiklik arz edebilmektedir. Bazı hizmetler büyük ölçeklere intiyaç duyarken bazıları küçük ölçekte daha etkin sunulabilmektedir. Ayrıca hizmetlerin niteliği kadar, orada yaşayan halkın talepleri de önemlidir. Öte yandan toplum statik değil dinamik bir yapıdadır. Sürekli değişkenlik gösterebilir. Dolayısıyla bugün optimal yani uygun olan ölçek yarın optimal olmayabilir. O nedenle en uygun büyüklüğü sağlamak adına yerel idareleri bölmek veya birleștirmek her zaman kamu yararına hizmet etmeyebilir.

Optimal ölçeği elde etmenin bir başka zorluğu ise veri elde etme konusudur. Yerel idarelerde optimal ölçek uygulamaları basit bir iktisadi formülle açıklanabilecek konu değildir. Kamu hizmeti, kamu yararı, toplumsal fayda vb., meseleler siyasi, sosyal, ekonomik ve coğrafi faktörleri bir arada barındıran derin bir konudur. Basit matematiksel tablolarla veya işlemlerle yörenin optimal büyüklüğünü elde etmek oldukça zordur. Dolayısıyla optimal ölçek, ülkeden ülkeye, aynı ülke içerisinde bölgeden bölgeye değişebilecek bir olgudur.

\section{Kaynakça}

Adıgüzel, Şenol (2012). “6360 Sayılı Yasa'nın Türkiye'nin Yerel Yönetim Dizgesi Üzerine Etkileri: Eleştirel Bir Değerlendirme”. Toplum ve Demokrasi Dergisi Yıl 6, Sayı 13-14, OcakAralık, s. 153-176.

Akdede, Sacit Hadi, ve Ertuğrul Acartürk (2005). "Türkiye'de İlçe ve Belediyelerin Optimizasyonu." Çağdaş Yerel Yönetimler 14(3): 5-17.

Göküş, Mehmet ve Alptürker, Hakan (2016). "6360 Sayılı Yasa ile Köy Yönetiminden Mahalle Yönetimine Geçiş Sonrası Etkin Hizmet Sunumuna ilişkin Muhtarların Görüşü: Silifke Köyleri Örneği”. Selçuk Üniversitesi Sosyal ve Teknik Araştırmalar Dergisi Sayı: 11(67-86).

Arıkboğa, Erbay (2007). "Yerel Yönetimlerde Ölçek Sorunu ve Belediye Reformu". Kayfor 2007, 18-20 Ekim, Kocaeli.
Atmaca, Yıldız (2013). "Optimal Belediye Büyüklüğü ve Yeni Büyükşehir Belediye Yasası". Çankırı Karatekin Üniversitesi İktisadi ve İdari Bilimler Fakültesi Dergisi 3(2): 168-184.

Aydınlı, Halil ibrahim ve Ahmet, Yılmaz (2004). "Demokrasi Tartışmaları Çerçevesinde II Özel Yönetimlerinde Valinin Konumu". Mevzuat Dergisi 7(13).

Bayraktar, Ulaş, https://ulasbayraktar.wordpress.com/2014/12/06/demokratiklesmeolcek-ekonomisi-ve-teknik-kapasite-arttirimiucgeninde-yeni-buyuksehir-duzenlemesi/, (Erişim tarihi: 25.08.2015.

Capello, Roberta, C., Roberto (2000). "Beyond Optimal City Size: An Evaluation of Alternative Urban Growth Patterns", Urban Studies 37(9): 1479-1496.

Çelikyay, Hicran (2014). "Değișen Kent Yönetimi ve 6360 Sayılı Büyükşehir Yasası”. SETA Analiz, Sayı: 101.

Çimen, Adnan (2013). "illçeler İçin "Optimal Ölçek” Belirleme Sorunu: illçe Kuruluşunda Yasama Süreci Üzerinde Bir İnceleme". Süleyman Demirel Üniversitesi iktisadi ve İdari Bilimler Fakültesi Dergisi 18(1): 339-365.

Çınar, Tayfun, Bülent Duru, Can Umut Çiner, Ozan Zengin (2013). "Belediyenin Sınırları". TODAiE, Ankara.

Çukurçayır, Akif (2014). "Büyükșehir Yasa Tasarısı Ne Şekilde Okunmalı?”, Radikal Yorum, (14.Nisan.2014)

Çukurçayır, Akif (2000). Siyasal Katılma ve Yerel Demokrasi. Ankara: Yargı Yayınevi.

Doğru, İsmail (2013). “Büyükşehir Belediyeleri ve Yeni Büyükşehir Kanunu'nun Sisteme Etkileri”. Sasam, http://sahipkiran.org/2013106/06/buyuksehir-belediyeleri-kanunununsisteme-etkileri/, Erişim Tarihi: 06.06.2013.

Eryılmaz, Bilal (2004). "Kamu Yönetiminde Değişim”. II. Kamu Yönetimi Forumu, 7-8 Ekim, Hacettepe Üniversitesi IïBF, Ankara.

Getz, Malcom (1979). “Optimum City Size: Fact or Fancy?". Law and Contemporary Problems, Vol. 43(2): 197-210. 
Gökçe, G., https://personel.omu.edu.tr/docs/ders_dokumanlari/1373_53729_1655.pdf, (19.08.2015).

Güryay, Erdal, A., Okan Veli (2005). "KKTC Belediyeciliğinde Ölçek Yapısının Finansal Etkileri Üzerine Bir Araştırma". Yönetim ve Ekonomi Dergisi 12(1).

Houlberg, Kurt (2000). "Municipal Size, Economy, and Democracy, Territorial Consolidation Reforms in Europe (Ed: Pawel Swianiewicz)". Local Government and Public Service Reform Initiative, Open Society Institute-Budapestss. ss. 309-329.

Illhan, Illhami (2011). “Türkiye'de Belediyelere iliş̧kin Yapısal Sorunlar”. SAYDER Dış Denetim Dergisi, No: 4.

Karaarslan, Mehmet (2012). "Nasıl Bir Yerel Yönetim? 6360 Sayılı Kanun Üzerine Bir Değerlendirme". Dicle Üniversitesi Hukuk Fakültesi Dergisi, 17(26).

Keleș, Ruşen (2004). Kentleşme Politikası. Ankara: Imge Kitabevi, 8. Baskı.

Keleş, Rușen (2006), Yerinden Yönetim Ve Siyaset, 5. Baskı, Cem Yayınevi, İstanbul.

Koyuncu, Emre, ve S., Selçuk, "Yerelleșmede Bir ileri İki Geri". TEPAV, http://www.tepav.org.tr/upload/files/132888 52437.Yerellesmede_Bir_lleri_lki_Geri.pdf, (Erişim Tarihi: 29.08.2015.

Kesgin, Bedrettin (2015). "Etkinlikle Demokratiklik Arasında Belediyeler, Yıl:7(4), ISSN: 1307-9832.

MiGM (Mahalli iddareler Genel Müdürlüğü) (1995). Belediyelerin Büyüklüğü, Etkinliği ve Halkın Katılımı. Ankara.

Nadaroğlu, Halil, ve Keleş., Ruşen (1991). "Merkezi idarelerle Mahalli idareler Arasındaki Mali i̇lișkiler". VII. Türkiye Maliye Sempozyumu, MÜ iiBF, 23- 25 Mayıs.

Özgür, Hüseyin (2002). "Türkiye de Küçük Belediyelerin Sorunlar ve Çözüm Önerileri" Avrupa Birliği le Bütünleșme Sürecinde Türkiye de Yerel Yönetimler, ed: B. Parlak \& H. Özgür, İstanbul : Alfa Yayınları.
Parlak, Bekir (2013). "Yeni Büyükşehir Belediye Yasasının Analizi", http://www.bursayerelyonetim.com/index.p hp/yeni-buyuksehir-belediye-yasasininanalizi/\#sthashkNwv3EsV.dpuf, Erişim Tarihi: 01.25.2013.

Șengül, Ramazan (2014). Yerel Yönetimler. Kocaeli: Umuttepe Yayınları.

TBB (2014). 6360 sayılı on dört ilde büyükşehir belediyesi ve yirmi yedi ilçe kurulması ile bazı kanun ve kanun hükmünde kararnamelerde değişiklik yapılmasına dair kanuna ilişkin rehber,

file://C:/Users/ASUS/Downloads/Documents/ 6360 torba personel rehber.pdf. Erişim Tarihi: 17.11.2017.

Tisdeil, Clem (1975). "The Theory of Optimal City-Size: Elementary Speculations about Analysis and Policy", Urban Studies, 12: 61-70.

Topal, Kadir (2011). "Kırsal Belediyelerde Optimal Büyüklüğü Belirlemeye Yönelik Bir Model Denemesi: Trabzon Örneği”". Marmara Üniversitesi IïBF Dergisi, 31(29): 367-380.

Urhan, V. Feyza (2007). “Türkiye'de Yerel Yönetimlerin Yeniden Yapılandırılması" Sayıştay Dergisi, Sayı: 70.

Zengin, Gökhan (2014). "Etkinlik ve Demokrasi Açmazında, 6360 Sayılı Kanun: Merkeziyetçi-Yerelleşme Anlayışının Yerel Özerklik Üzerine Etkileri”. KAYFOR 12.

Zengin, Ozan (2014). "Büyükşehir Belediyesi Sisteminin Dönüşümü: Son On Yılın Değerlendirmesi”. Ankara Barosu Dergisi. 